new doctrine like to believe, however remote the possibility of realization, that their candidates will shortly sweep into the seats of political power, and the promise of such an event is an effective means of gaining support. And finally, of course, there is always the possibility of the minor party actually replacing one of the major parties, a possibility which, though remote, should not be ignored.

\title{
THE GROWTH OF THE INTERNATIONAL SHOE DOCTRINE
}

When residents of one state carry on business in another state through their agents, the courts of the latter state cannot acquire jurisdiction in personam over the nonresidents under the historical prerequisite of the presence of the

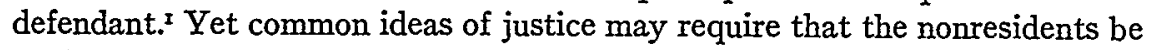
subject to suit in the courts of the state in which they are doing business. Until recently, the principal's absence from the state was thought to deny its courts any power over him, if he were an individual. When the principal was a juristic person further complexities appeared, ${ }^{2}$ but the courts found it easier to develop jurisdictional doctrines to meet the situation. Thus, under some circumstances, the foreign corporation may be denied the privilege of doing business in the state unless it has designated an agent in the state upon whom service of process may be made. In the absence of such express consent by the corporation to the exercise of jurisdiction, ${ }^{3}$ proper service of process ${ }^{4}$ may nevertheless give a court jurisdiction to render a personal judgment against the corporation. This power has been based upon various concepts, the courts most often referring to the "implied consent" of the corporation to the exercise of jurisdiction, ${ }^{5}$ or to the "presence" of the corporation wherever its activities are being carried on. ${ }^{6}$ The

$x$ Unless, of course, the nonresident, if an individual, happens into the state at an opportune moment.

${ }^{2}$ Early in the nineteenth century it was thought impossible to acquire jurisdiction in personam over a foreign corporation. Middlebrooks v. Springfield Fire Ins. Co., I4 Conn. $3^{\circ I}$ (184I); Henderson, The Position of Foreign Corporations in American Constitutional Law 77 et seq. (I9I8).

3 When the corporation has expressly consented to jurisdiction over it, the extent of the authority thereby conferred is a question of interpretation of the instrument of consent or of the statute requiring it. Thus, the authorization of the agent to accept service of process may include causes of action arising in other states. Pennsylvania Fire Insurance Co. v. Gold Issue Mining and Milling Co., 243 U.S. 93 (I9I7); Smolik v. Philadelphia \& Reading Coal and Iron Co., 222 Fed. 148 (D.C. N.Y., rgr 5). Or it may be construed to refer only to causes of action arising out of business done in the state. Dunn v. Cedar Rapids Engineering Co., I52 F. 2d 733 (C.C.A. 9th, I945). Cases involving express consent are not considered in this note.

4 Of course, a judgment against a foreign corporation, or any other defendant, is void unless the method of service employed is reasonably calculated to give notice to the defendant and to afford it an opportunity to be heard. Rest., Judgments $\$ \S 6,3 \circ$ (I942); I Beale, Conflict of Laws $\$ 89.3$ (I935). This note is concerned with the other element of jurisdiction-the power of a state to subject a person to its control.

$s$ Lafayette Insurance Co. v. French, r8 How. (U.S.) 404 (1855); Mutual Life Insurance Co. v. Spratley, 172 U.S. 602 ( 1899 ).

${ }^{6}$ International Harvester Co. v. Kentucky, 234 U.S. 579 (19I4); Philadelphia \& Reading Ry. Co. v. McKibbin, 243 U.S. 264 (I9r7); Bank of America v. Whitney Cent. Nat. Bank, 261 U.S. I7I (I923). 
fictional character of both these theories, as well as their inadequacy to explain the decisions, has been demonstrated. ${ }^{7}$ Under either appoach, the extent of the activities of the foreign corporation within the state of the forum is of major significance. This is recognized by the courts in the phrase "doing business," which not only expresses a conclusion of fact but also denotes the result of a policy judgment. ${ }^{8}$

The fictions were at last expressly discarded by the Supreme Court in International Shoe Co. v. Washington, Chief Justice Stone asserting:

To say that a corporation is so far "present" there as to satisfy due process requirements ... is to beg the question to be decided. For the terms "present" or "presence" are used merely to symbolize those activities of the corporation's agent within the state which courts will deem to be sufficient to satisfy the demands of due process. ... Those demands may be met by such contacts of the corporation with the state of the forum as make it reasonable, in the context of our federal system of government, to require the corporation to defend the particular suit which is brought there. An "estimate of the inconveniences" which would result to the corporation from a trial away from its "home" or principal place of business is relevant in this connection.9

Thus, jurisdiction in personam was constitutionally acquired over the defendant corporation because its operations had established "sufficient contacts or ties with the state of the forum to make it reasonable and just according to our traditional conception of fair play and substantial justice" ${ }^{30}$ to subject it to suit there. This new test of reasonableness and justice involves a balancing of conflicting interests in a manner not unlike the determination of a forum non conveniens question. ${ }^{\text {Ix }}$ Although it may be no less vague and uncertain than the

7 "Implied consent": L. Hand, J., in Smolik v. Philadelphia \& Reading Coal and Iron Co., 222 Fed. I48 (D.C. N.Y., I9 5 ); I Beale, Conflict of Laws \$ 89.7 (I935); Henderson, op. cit.

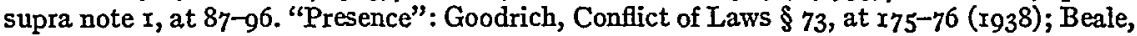
supra, at $\$ 89.6$; Farrier, Jurisdiction over Foreign Corporations, $x 7$ Minn. L. Rev. 270, 280-8I, (1933).

${ }^{8}$ Thus, though it may be an admitted fact that the corporation is transacting a certain amount of business in the state, the courts often say that the corporation is "not doing business" in the state. Such a statement means that the court believes the corporation's activities are not so extensive as to make it reasonable to require it to defend or suffer judgment by default.

${ }^{9} 326$ U.S. 3I0, 3I6-I7 (I945). As to "implied consent": "True, some of the decisions holding the corporation amenable to suit have been supported by resort to the legal fiction that it has given its consent to service and suit, consent being implied from its presence in the state through the acts of its authorized agents... . But more realistically it may be said that those authorized acts were of such a nature as to justify the fiction." Tbid., at 3 I8.

so Ibid., at 320.

II In the opinion of Judge Learned Hand, the case holds that in order to determine jurisdiction "the court must balance the conflicting interests involved; i.e., whether the gain to the plaintiff in retaining the action where it was, outweighed the burden imposed upon the defendant; or vice versa. That question is certainly indistinguishable from theissue of 'forum non conveniens.' " Kilpatrick v. Texas \& P. Ry. Co., I66 F. 2 d 788 (C.C.A. 2d, I948), cert. den., 69 S. Ct. 32 ( 1948$)$. The reasoning of the Court in the International Shoe case relies considerably on that of Judge Hand in Hutchinson v. Chase \& Gilbert, 45 F. 2 d I39 (C.C.A. 2d, I930). 
"presence" theory, ${ }^{12}$ it does place the determination of jurisdiction on a more realistic basis. Moreover, the opinion supplements the broad general test with two further questions: whether the activities of the foreign corporation within the state have been continuous and systematic or only single or isolated acts, and whether or not the activities gave rise to the liabilities sued on.

\section{I}

Both the broad test stated in the International Shoe case and its general language seem clearly to imply that courts may constitutionally exercise greater freedom than they might have formerly in subjecting foreign corporations to in personam actions. ${ }^{\mathrm{x}}$ It may be interesting to examine subsequent cases in the state and lower federal courts in an effort to learn to what extent the potentialities of that case have been realized. ${ }^{14}$ As might be expected, application of the standards of the International Shoe case has been objected to on the ground that they apply only to matters of special state regulation and not to general jurisdictional questions. This view has been generally rejected, ${ }^{15}$ and is without support in the case itself. The Court expressly dealt with two questions, jurisdiction for purposes of suit and jurisdiction to tax, but the opinion was chiefly concerned with the former. Nor did the language of the Court in any way suggest that the authority of its holding was to be limited to actions brought by a state to recover unemployment compensation contributions.

It seems clear that one result of the International Shoe case is to require less corporate activity within the state than was required in the past as a basis for asserting jurisdiction. In other words, a given quantity and quality of activities may now be held to constitute "doing business" for purposes of subjection to suit, ${ }^{16}$ although such activities would not formerly have amounted to "doing

x2 See McBaine, Jurisdiction over Foreign Corporations: Actions Arising out of Acts Done within the Forum, 34 Calif. L. Rev. 33I, 336 (I946), criticizing the case on this ground.

${ }^{I_{3}}$ It is, in a sense, true that the Court "engaged in an unnecessary discussion in the course of which it ... announced ... Constitutional criteria applied for the first time...," as Justice Black stated in his concurring opinion. International Shoe Co. v. Washington, 326 U.S. 310,323 (1945). Since the same result could have been reached by a slight advance in the application of prior doctrines, the tests stated might be considered dicta. But, for the same reason, it appears that the majority of the Court felt very strongly about the need for new criteria in jurisdictional matters, and it seems reasonable to believe that the Court will hold to the doctrines of the case for some time to come. Any change would most likely be a further extension.

${ }^{4}$ Although the decisions as to jurisdiction over foreign corporations depend in the first instance upon the construction of statutes providing for service of process, this statutory interpretation is usually keyed to constitutional interpretation. Thus, an extension of constitutional power may be reflected in the cases without the enactment of new legislation.

${ }_{25}$ Wooster v. Trimont Mfg. Co., $35^{6}$ Mo. 682, 203 S.W. 2d 4II (I947); State v. Ford Motor Co., 208 S.C. 379 , 38 S.E. $2 \mathrm{~d} 242$ (1946). Contra: Bomze v. Nardis Sportswear, Inc., 68 F. Supp. 156 (N.Y., 1946), rev'd I65 F. $2 d 33$ (C.C.A. 2d, I948); Murray v. Great Northern Ry. Co., 67 F. Supp. 944 (Pa., I946).

${ }^{26}$ What constitutes "doing business" by a foreign corporation may be important for at least three purposes: $I$ ) to determine jurisdiction for service of process (which is the only 
business." The Court has apparently done away with the "mere solicitation rule" which had become attached to the concept of "doing business."17 One frequently recurring "mere solicitation" fact situation is that of the foreign railroad corporation, engaged in soliciting freight and passenger business. The facts in a New York federal district court case ${ }^{18}$ are typical: The defendant corporation maintained a New York office, where eight persons were employed, for the sole purpose of solicitation of freight and passenger business. No bills of lading were issued at this office, no settlements of claims made, and no tickets sold, since the railroad had no tracks in New York and its customers there consequently bought their tickets from lines which connected with the defendant's. It was also found that various New York trust companies acted as registrars, trustees, stock transfer agents, and interest disbursing agents of the corporation's security issues. The district court applied the "mere solicitation rule," wi without referring to the International Shoe case, and granted the defendant's motion to dismiss, ${ }^{20}$ since the defendant was not "doing business" within the district. ${ }^{2 x}$ This decision was reversed in the circuit court, ${ }_{2}^{22}$ Judge Learned Hand stating:

aspect of the concept considered here); 2) to determine jurisdiction to tax; 3) to determine whether or not the corporation must "domesticate." Rest., Conflict of Laws $\S$ I67 (I934); Roberts, What Constitutes "Doing Business" by a Foreign Corporation in Kentucky, $3 x \mathrm{Ky}$. L. J. 3 (I942). The content of the concept varies according to its use; "doing business" for one purpose may not be "doing business" for another purpose. State v. Ford Motor Co., 208 S.C. 379,38 S.E. $2 \mathrm{~d} 242$ (I946) (corporation held subject to jurisdiction for service of process but not subject to domestication requirements).

${ }^{17}$ The "rule" - that solicitation alone, without other activities on the part of the agents within the state, was not "doing business"--perhaps originated in Green v. Chicago, Burling-

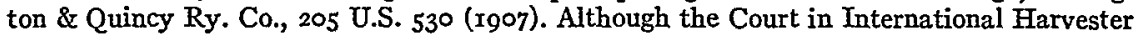
Co. v. Kentucky, 234 U.S. 579 (I9I4), called the Green case "extreme," it went on to find that "[i]n the case now under consideration there was something more than mere solicitation."

${ }^{18}$ Kilpatrick v. Texas \& P. Ry. Co., 72 F. Supp. 635 (N.Y., 1947).

I9 "It will be enough to refer to the leading case of Green v. Chicago, B. \& Q. R. Co., 205 U.S. $53^{\circ} \ldots$ which has ... never been overruled, either expressly or impliedly . ..." Ibid., at 638 . Accord: Murray v. Great Northern Ry. Co., 67 F. Supp. 944 (Pa., I946).

${ }^{20}$ Several courts, relying on the International Shoe case, have reached the opposite result on comparable facts. Lasky v. Norfolk \& W. Ry. Co., I57 F. 2d 674 (C.C.A. 6th, I946); Willett v. Union Pacific R. Co., 76 F. Supp. 903 (Ohio, x948); Butts v. Southern Pac. Co., 69 F. Supp. 895 (N.Y., I947); Nunn v. Chicago, M., St. P. \& Pac. R. Co., 7I F. Supp. 54I (N.Y., r947) (following the Butts case); cf. Vincent v. Ann Arbor R. Co., 73 F. Supp. 729 (N.Y., I947) (same result without reference to the International Shoe case).

${ }^{2 x}$ The action was for damages for personal injuries under the Federal Employers' Liability Act, for which the venue provision reads: "Under this chapter an action may be brought in a district court of the United States, in the district of the residence of the defendant, or in which the cause of action arose, or in which the defendant shall be doing business at the time of commencing such action...." 35 Stat. 66 (Igo8), as amended, 45 U..S.C.A. $\$ 56$ (r943). The extent of activities which equals "doing business" under this statute is apparently the same as that which is necessary to make the foreign corporation amenable to suit in other cases. Precedents in the two types of cases are used interchangeably. Cases cited note zo supra.

${ }^{22}$ Kilpatrick v. Texas \& P. Ry. Co., I66 F. 2 d 788 (C.C.A. 2d, I948), cert. den. 69 S. Ct. 32 (1948). 
[S]o far as it [the foreign corporation] must be "present" in order to satisfy the territorial limitation upon the powers of a court when acting in personam, it should be enough constitutionally that it shall have extended its activities into the territory where that court's process runs. If that is true, the question whether it must stand trial in the particular forum which the plaintiff has chosen is . . identical with the plea of "forum non conveniens."

This is the effect of the International Shoe case. Consequently, since the defendant in this instance was not aided by forum non conveniens principles, ${ }^{24}$ its motion to dismiss should have been denied, in the opinion of the circuit court. It may be noted that the corporation here did something slightly more than merely solicit orders. It should be pointed out, however, that it is difficult to imagine a case in which a court could not find that the corporation engaged in something more than "mere" solicitation. ${ }^{25}$ The form of the rule is of little importance if the rule has no substance. Since the International Shoe case, the substance is gone, and the form is fast disappearing. Continuous solicitation of business may alone be sufficient activity to make the foreign corporation subject to the personal jurisdiction of a court of the state where the solicitation is done, at least so long as the cause of action is one arising out of the business done, since the court would then normally be the forum of convenience for the action. ${ }^{26}$

23 Ibid., at 79 r.

${ }^{24}$ Although the case involved a foreign cause of action, the defendant could not be aided by forum non conveniens principles because, in actions under the Federal Employers' Liability Act, the venue provision of that Act (note 2I supra) had been construed to give the plaintiff a choice of forum which could not be defeated on the basis of forum non conveniens. Baltimore \& Ohio R. Co. v. Kepner, 3I4 U.S. 44 (x94r); Miles v. Illinois Central R. Co., 3I5 U.S. 698 (r942); cf. United States v. National City Linés, 334 U.S. 573 (I948) (similar doctrine in civil suits to enjoin violations of Sherman Act). The Kepner doctrine has, however, been abrogated by the new Judicial Code. 28 U.S.C.A. \& I404(a) (I948). Forum non conveniens has since been applied in actions under the Federal Employers' Liability Act. Nunn v. Chicago, Milwaukee, St. P. \& P. R. Co., 80 F. Supp. 745 (N.Y., I948); Hayes v. Chicago, R.I. \& P. R. Co., 79 F. Supp. 82 (Minn., 1948); cf. United States v. National City Lines, 80 F. Supp. 734 (Cal., 1948) (suit for injunction under Sherman Act). Ordinarily, the fact that the cause of action did not arise out of business done within the state would be significant, if not decisive, as to jurisdiction over the foreign corporation. This should not detract from the significance of the Kilpatrick decision as to the extent of activities necessary for jurisdiction in all cases.

25 In the following cases, the defendants' activities were held to be more than "mere solicitation": Marlow v. Hinman Milking Mach. Co., 7 F.R.D. 75 I (Minn., 1947) (agents advised dealers and sometimes "even performed minor repairs" on machines); State v. Ford Motor Co., 208 S.C. 379,38 S.E. 2 d 242 (1946) (control over automobile dealers througb contracts); International Shoe Co. v. Washington, 22 Wash. 2d 146, I54 P. 2d 80r (1945) (salesmen sometimes rented sample rooms).

${ }^{26}$ In situations involving foreign corporations other than railroads, the activities of the corporate agents being mainly, if not entirely, solicitation, the defendants were beld subject to jurisdiction in the following cases, the courts expressly following the International Shoe case: Bomze v. Nardis Sportswear, Inc., 165 F. 2d 33 (C.C.A. 2d, 1948), (reversing lower court which had followed "mere solicitation" rule); Schmikler v. Petersime Incubator Co., 77 F. Supp. II (Mass., I948); Marlow v. Hinman Milking Mach. Co., 7 F.R.D. $75^{1}$ (Minn., 1947); Wooster v. Trimont Mfg. Co., 356 Mo. 682, 203 S.W. 2d 4rI (r947); State v. Ford Motor Co., 208 S.C. 379,38 S.E. 2 d 242 (1946). One court thought the International Shoe decision upheld the "mere solicitation" rule, but the corporation's local agent had engaged in so many 
Ample authority may be found in the International Shoe case for this proposition. ${ }^{27}$

Illustrative of the changes in ways of transacting business which require corresponding changes in jurisdictional doctrines is the case of the mail order insurer. In a case ${ }^{28}$ involving the South Carolina Uniform Unauthorized Insurers Act, ${ }^{29}$ the defendant Mllinois corporation, which had no office, property, or agents within South Carolina, had insured the plaintiff's husband by mail, after his inquiry responding to the insurer's advertisement in a national publication. The plaintiff beneficiary, seeking to recover on the policy in a federal district court, was met with jurisdictional objections. The Act provides:

The transacting of business in this state by a foreign or alien insurer without being authorized to do business in this state and the issuance or delivery by such foreign or alien insurer of a policy ... to a citizen of this state or to a resident thereof ... is equivalent to an appointment by such insurer of the Commissioner of Insurance [as agent for service of process] in any action ... arising out of such policy. ${ }^{30}$

Relying considerably on the International Shoe case, the court found that the primary purpose of the statute was to afford the parties judicial facility for settling disputes "according to our traditional conception of fair play and substantial justice" ${ }^{3 \mathrm{x}}$ and without undue inconvenience to either party:

[W]ithout such an Act, an insurer could say to an insured, or to his beneficiary, in case of a controversy respecting liability under a policy, that the issue between them could be settled in only one of two ways, first, by accepting the insurer's contention or, second, by suing the insurer in its own bailiwick. ${ }^{32}$

other activities for the defendant that the corporation was easily held to be "doing business" anyhow. New v. Robinson-Houchin Optical Co., 357 Pa. 47, 53 A. 2d 79 (1947). Without apparent notice of the Shoe case, the court in McWhorter v. Anchor Serum Co., 72 F. Supp. 437 (Ark., 1947), followed the "mere solicitation" rule and dismissed the action for lack of jurisdiction. In Deaton Truck Lines, Inc. v. Bahnson Co., 207 S.C. 226, 36 S.E. $2 d 465$ (x945), the court seemed to proceed under the impression that so long as the corporation's activities were interstate commerce and not intrastate business, the corporation was not subject to service of process in the state. But cf. State v. Ford Motor Co., 208 S.C. 379, 38 S.E. 2 d 242 (I946). It was clearly established in International Harvester Co. v. Kentucky, 234 U.S. 579 (rgI4), that interstate commerce alone might render a corporation subject to suit outside the state of its organization.

${ }^{27}$ The opinion of the Supreme Court in the International Shoe case does not directly overrule the "mere solicitation" rule; rather, it removes the foundation for the rule with the introduction of the test of reasonableness and justice. If only the material facts and the decision in the case are considered, without reference to the remainder of the opinion, the "mere solicitation" rule clearly appears to be destroyed. Compare the similar handling of the situation in Bomze v. Nardis Sportswear, Inc., I65 F. 2d 33 (C.C.A. 2d, 1948). It is interesting to note that the Supreme Court, in the International Shoe case, did not use the phrase "doing business" except in reciting the contentions of the appellant and the holding of the Washington court.

${ }^{28}$ Storey v. United Ins. Co., 64 F. Supp. 896 (S.C., I946).

${ }^{29}$ S.C. Code of Laws (Supp., 1944) §8020. The Act has been adopted in Arkansas, Louisiana, and South Dakota, as well as South Carolina. 9 U.L.A. I98 (Supp., 1948). No other cases concerning its validity seem to have appeared.

$3^{\circ}$ S.C. Code of Laws (Supp., 1944) $\$ \S 8020-5$.

${ }^{3 x}$ Storey v. United Ins. Co., 64 F. Supp. 896, 898 (S.C., I946).

32 Ibid. 
The court declared that the state legislature had the right to define what acts constitute doing business so long as its definition "was not arbitrarily unreasonable," ${ }^{33}$ and denied the defendant's motion to set aside service of process. Probably few would question the reasonableness or the justice of this decision. It is therefore in accordance with the constitutional doctrines of International Shoe Co. v. Washington..$^{34}$

The distinction between continuous and systematic activities and single or isolated acts by the foreign corporation's agents within the state is one of the criteria supplementing the broad test of reasonableness in the International Shoe opinion. The Court does not foreclose the possibility that isolated activity could result in proper subjection of the corporation to suit so long as the cause of action arose out of that activity, ${ }^{35}$ although the opinion recognizes something of a presumption against such a possibility. Nevertheless, it would not be entirely unreasonable to provide, for example, that courts of a particular state should have jurisdiction over all disputes arising out of contracts made (or to be performed) within the state, regardless of the number of contracts of the defendant which were made (or to be performed) there. ${ }^{36}$ Moreover, the Court in the International Shoe case implies that the test as to what activities will subject the foreign corporation to suit is qualitative, not "simply mechanical or quantitative." 37

Perhaps the attitude of state courts in recent decisions may be illustrated by a Pennsylvania case $^{38}$ in which a steamship corporation was the defendant. Four

33 Ibid., at 900.

34 In Cindrich v. Indiana Travelers Assur. Co., 356 Mo. ro64, 204 S.W. 2d 765 (1947), a similar case involving a similar statute, the Missouri Supreme Court felt "constrained to rule" that the statute did not apply to the transactions of the insurer "in view of" Minnesota Commercial Men's Ass'n v. Benn, 26x U.S. 140 (1923). The court did not mention International Shoe Co. v. Washington.

3s Indeed, it is implied that where the single or isolated acts are of a sort dangerous to life or property, the corporation may be constitutionally subjected to suit on causes of action arising out of such acts. International Shoe Co. v. Washington, 326 U.S. $310,3 \times 8$ (I945). This is stated to be the law in Rest., Judgments $\S 28$ (1942). However, the proposition has in the past met with difficulties in the courts. Goodrich, Conflict of Laws $\$ 73$, at $178-79$ (1938).

${ }^{36}$ In England, Order XI of the Rules of the Supreme Court provides for service out of the jurisdiction whenever the "action is one brought against a defendant ... to enforce, rescind, dissolve, annul or otherwise affect a contract or to recover damages or other relief for or in respect of the breach of a contract-(i) made within the jurisdiction, or (ii) made by or through an agent trading or residing within the jurisdiction on behalf of a principal trading or residing out of the jurisdiction ... or is one brought ... . in respect of a breach committed within the jurisdiction of a contract wherever made. ..." Annual Practice 96-7 (I947). The power of English courts to permit service on an absent defendant under these rules is discretionary. The court may refuse to exercise jurisdiction if the resulting hardship upon the defendant would be too great. Service out of the jurisdiction is, however, frequently allowed. Annual Practice ro8-I4 (I947); Wolff, Private International Law 67-69 (I945); Cheshire, Private International Law III-I5 (x938); cf. Ross v. Ostrander, 79 N.Y.S. 2d 706 (Sup. Ct., 1948) (refusing recognition to English judgment against American promisor served in N.Y.).

37 International Shoe Co. v. Washington, 326 U.S. 3 IO, 3 I9 (I945).

${ }^{38}$ Holliday v. Pacific Atlantic S.S. Corp., 354 Pa. 27I, 47 A. 2d 254 (I946). 
ships operated by the defendant came to Philadelphia in the year in which process was served. When in the port, the ships were "turned around" by a local concern which arranged for pilots, a berth for the ship, towboats, paying off the crew, and signing a new crew. This concern acted for the defendant only when its ships came to Philadelphia, performing no other services for the defendant. The court thought that there was "not enough in the record to sustain ... a judgment in personam" 39 against the corporation. The court apparently found nothing to the contrary in its quotations from the International Shoe opinion. Although the question of degree as to what are isolated acts and what are continuous activities must often be a matter of argument, in recent cases clearly involving isolated acts the courts have not attempted to claim jurisdiction over the nonresident defendant..$^{\circ}$

Aside from the extent of the activities of the corporation within the forum, the significant supplementary test announced by the Supreme Court in the International Shoe case is whether or not the cause of action arose from those activities..$^{4 x}$ If the activities are only single or isolated acts and the cause of action is unconnected with them, it is probably still unconstitutional to subject the corporation to suit. However, if the corporate operations within the forum are continuous and substantial, even though the cause of action did not arise from those operations, the implication of the International Shoe opinion is that it is not necessarily unconstitutional to require the corporation to defend the

39 Ibid., at 275, 256. In Holland v. Parry Nav. Co., 7 F.R.D. 47I (Pa., 1947), on almost precisely the same facts, the defendant was held to have been "doing business" in Pennsylvania sufficient to make it amenable to service, although the defendant's motion to vacate service was granted because the person served was not considered a proper party for service under the Pennsylvania statute; cf. Oro Nav. Co. v. Superior Court, 82 Cal. App. 2d 884, I87 P. 2d 444 (I947) (defendant's ship prepared for operation and crew hired in state).

${ }_{40}^{\circ}$ The defendant's activities, arguably within the "isolated acts" class, were held not to constitute "doing business" for jurisdictional purposes in Read v. La Salle Extension University, I56 F. 2d 575 (App. D.C., I946) (solicitation of students on commission basis by one entirely independent representative, paying own expenses); Yedwab v. M. A. Richards Corp., I37 N.J.L. 448, 60 A. 2d 3 Io (I948) (advising dealer as to merchandise display); Harrub v. Hy-Trous Corp., 3r So. $2 \mathrm{~d} 567$ (Ala., x947) (visit by defendant's president to confer with independent local distributor); Hellman v. Ladd, $3^{x}$ Mich. I5O, 23 N.W. $2 d 244$ (I946) (advising and assisting supplier); Condon-Cunningham Co. v. Caterpillar Tractor Co., 64 F. Supp. 92r (Neb., I946) (maintaining one representative to "create good will" and "enthuse and advise distributors"); Geller v. Macon, D. \& S. R. Co., I9० N.Y. Misc. 903, 75 N.Y.S. 2d 8 I8 (I947) (negotiating bond refunding and occasional visits by agent to solicit freight business). In the following cases, it also appeared that the cause of action was not one arising out of the business done: Fehlhaber Pile Co. v. Tennessee Valley Authority, I55 F. 2d 864 (App. D.C., I946) (government-owned corporation maintaining Washington office for public and intergovernmental relations purposes); Rogers v. Mountain States Royalties, Inc., II6 Colo. 455, I82 P. 2d I42 (I947) (holding directors' meetings in state); Wolfer v. Lit Bros., I35 N.J.L. 253, 5r A. 2d I5 (r947) (lone agent soliciting by telephone from private apartment); Central Motor Lines v. Brooks Transp. Co., 225 N.C. 733, 36 S.E. 2d 27I (I945) (owning unused intrastate franchise and making occasional trips into state).

${ }_{4} \mathrm{I}$ It should be noted that a cause of action may arise in State $A$ and yet arise out of business done in State B. The distinction here is not between causes of action arising in the state of the forum and those arising elsewhere. 
action away from its "home." ${ }^{2}$ Apparently no court has yet found it desirable to utilize this opportunity, for subsequent cases have uniformly dismissed such actions. ${ }^{43}$ Perhaps this is because no case has appeared in which it would have been clearly in accord with ordinary notions of "fair play and substantial justice" to assert jurisdiction over such an action. ${ }^{44}$ Cases can be imagined, however, in which it would be no hardship upon the corporation to defend an action in a state in which it was doing business, even though the action had no relation to that business. 45 Defendants have been known to interpose jurisdictional objections without regard to the amount of hardship upon them, or upon the plaintiff if those objections should prevail. In balancing the conflicting interests of the parties with regard to the relative burden in assuming or rejecting jurisdiction, the weight may sometimes be on the plaintiff's side, regardless of the origin of the cause of action. On the other hand, a possible party, though he may be rare, is the plaintiff who seeks to recover a default judgment on the basis of an unjust claim, small enough to be exceeded by the amount it would cost the defendant to rebut the claim. Moreover, since it will probably most often be unreasonable to force the corporation to defend an unrelated foreign cause of

${ }_{42}$ This is contrary to what had previously been thought the law. Rest., Conflict of Laws $\S 92$ (I934); I Beale, Conflict of Laws $\S 89.4$ ( 1935 ); Goodrich, Conflict of Laws $\S 73$, at I 76-77 (1938). This earlier conclusion was based on Old Wayne Mutual Life Ass'n of Indianapolis v. McDonough, 204 U.S. 8 (I907), and Simon v. Southern Ry. Co., 236 U.S. II 5 (IgI4). No opinion was expressed on the question in Rest., Judgments $\$ 30$ (I942). In Central Motor Lines v. Brooks Transp. Co., 225 N.C. 733, 36 S.E. 2d 27I (1945), the court, after discussing the International Shoe case, said: "We have not found the authority of the Wayne case and the Simon case successfully distinguished, or disputed, upon the factual situations which they present. . .." Ibid., at 276 . But the supposed authority of those cases seems clearly limited by standards presented by the International Shoe case. The Simon and Wayne cases have been distinguished before. Tauza v. Susquehanna Coal Co., 220 N.Y. 259, II 5 N.E. 915 (I9I7).

${ }^{43}$ Smith v. Hydro Gas Co. of West Florida, 157 F. 2d 809 (C.C.A. 5th, 1946), cert. den. 330 U.S. 844 ( $x_{947}$; Mueller Brass Co. v. Alexander Milburn Co., ${ }_{52}$ F. 2 d 142 (App. D.C., I945); Fehlhaber Pile Co. v. Tennessee Valley Authority, I55 F. 2d 864 (App. D.C., I946); Landaas v. Canister Co., 69 F.Supp. 835 (N.Y., I946); Rogers v. Mountain States Royalties, Inc., I 6 Colo. 455, I82 P. 2d 142 (I947); Central Motor Lines v. Brooks Transp. Co., 225 N.C. 733, 36 S.E. 2d 27I (1945); D. W. Onan \& Sons v. Superior Court, 65 Ariz. 255, I79 P. 2d 243 (1947); Wolfer v. Lit Bros., I35 N.J.L. 253, 5I A. 2d I5 (1947). In some of these cases it was simply held that the defendant was not "doing business" in the state, and whether the relevance of the cause of action was considered does not appear.

${ }_{44}$ However, in actions under the Federal Employers' Liability Act prior to enactment of the new Judicial Code, if the defendant was found to be "doing business" in the district, it made no difference where the cause of action arose, in view of the interpretation of the venue provision of that statute. Note 24 supra.

45 Such as an action to recover the amount due on a negotiable instrument on which the foreign corporation is unquestionably the party primarily liable, the issue concerning only the negotiation of theinstrument to the plaintiff in the state of the forum or the construction of the terms of the instrument in view of the formal requisites of negotiability. Generally, there will be no substantial hardship on the defendant in cases where the corporation has no real defense on the merits, where the facts are not in dispute and the issue is one of law, or where the disputed facts may be determined from the testimony of witnesses readily available to the forum. 
action, it might be well to refuse all such actions in the interests of certainty, unless a definite type can be clearly set apart from the others.

Several foreign corporation jurisdiction cases involve, in effect, the question: Who is doing business? The facts in Bach v. Friden Calculating Mach. Co.46 will serve as an illustration: An alleged agent of the defendant California corporation sold, serviced, and repaired the defendant's machines in Ohio. The defendant contended that the alleged agent was an independent contractor. The court studied the contract between the defendant and the "independent contractor," which seemed to be formally prepared to appear like an agreement with an independent contractor, but which revealed very extensive control by the corporation over that party's business operations.47 Recognizing the "broadened viewpoint" of the International Shoe case, the court thought that, in accordance with the test of reasonableness and justice, "[m]ere formalism should give way to the real substance of the agreement. . . " ${ }^{8}{ }^{8}$ The lower court's decision for the defendant was therefore reversed. Other courts agree in similar cases, ${ }^{49}$ and there can be little question as to their correctness, for "traditional notions of fair play and substantial justice" do not allow the defendant to disown its activities when they give rise to obligations. Of course, if the alleged agent is actually independent, as in the ordinary wholesaler-retailer relationship, the activities of the retailer cannot constitute "doing business" by the wholesaler..$^{50}$ Who is "doing business" is largely a question of fact and, it would

${ }^{46}$ I67 F. $2 \mathrm{~d} 679$ (C.C.A. 6 th, I948).

47 The contract provided that the agent should not further the interest of any of the corporation's competitors, or engage in any other general business without the corporation's consent. The agent was required to sell at prices fixed by the corporation, to locate in a place acceptable to the corporation, to operate under a name similar to the corporation's, and to give the corporation free access to his files. The agent agreed to maintain liability insurance on vehicles used in the business to an amount satisfactory to the corporation. The agent was forbidden to mortgage any machine in his possession, or to become a surety or endorser without the corporation's consent. The agent took orders in the name of the corporation, and his customers remitted to the corporation. Ibid.

$4^{8} \mathrm{Ibid}$., at 683 .

${ }^{49}$ Harrison v. Corley, 226 N.C. I84, 37 S.E. $2 d 489$ (x946) (agent operating airports for corporation under contract ostensibly a "lease"); Littman v. Morris B. Sachs, Inc., 65 N.Y.S. 2d 754 (Sup. Ct., r946) (local corporation acting as buying agent for defendant); cf. Clover Leaf Freight Lines v. Pacific Coast Wholesalers Ass'n, I66 F. 2d 626 (C.C.A. 7th, I948), cert. den. 69 S. Ct. 46 (1948) (freight forwarding agent). Each of the preceding cases expressly followed the International Shoe case; the Clover Leaf case is a particularly well-reasoned application of the principles laid down by the Supreme Court. In Giusti v. Pyrotechnic Industries, 156 F. 2d 35 I (C.C.A. gth, 1946), cert. den. sub nom. Triumph Explosives, Inc. v. Giusti, 329 U.S. 787 (I946), an express consent case, the court held that the defendant's unfair trade practices, although wrongful, nevertheless amounted to "business transacted" in California for jurisdictional purposes. California firms which were members of the monopolistic conspiracy were held agents through which the "business" was transacted.

so The independence of the alleged agent was the decisive factor against jurisdiction in Landaas v. Canister Co., 69 F. Supp. 835 (N.Y., I946) (lone salesman paid own expenses); Guile v. Sea Island Co., 66 N.Y.S. 2d 467 (Sup. Ct., I946), aff'd without opinion 272 App. Div. 88I, 7x N.Y.S. 2d 9rx (r947), appeal dismissed 297 N.Y. 78x, 77 N.E. 2d 793 (r948) (local corporation soliciting guests for defendant's resort hotel); and influential in Read v. La Salle 
seem, not altogether dependent upon the law of agency.5I

Although the broad test of the International Shoe case has been expressly adopted as controlling in many decisions $5^{52}$ the potentialities of those standards are far from realized. ${ }^{53} \mathrm{~A}$ general review of subsequent cases reveals some courts still speaking in terms of "implied consent" ${ }^{54}$ or "presence." 5 Probably the most significant feature of the case was its removal of the problem from "that world of abstraction-drawn from the analogy of arrest under a capias-in which it has hitherto so helplessly floundered." ${ }^{60}$ The fictions no longer have any proper place in the decisions. Their misleading and confusing influence should not be perpetuated in dealing with a problem which has none but real aspects to the parties involved and which can be measured by the plaintiffs and defendants in terms of convenience, money costs, and injustice. Although extension of the jurisdiction of courts may be expected to continue in the wake of scientific and economic developments, the specific possibilities of extension discussed above may not all develop in the near future, since they often involve situations in which there may be considerable difference of opinion as to the reasonableness of assuming jurisdiction over a particular defendant or class of defendants. But there is surely no necessity for dealing in outworn abstractions when the Supreme Court has stated the issue in terms of the considerations actually involved. The broad standards of the International Shoe case may be expected to prevail in a mature legal system.

Extension University, I56 F. 2d 575 (App. D.C., I946). Cf. Minnesota Mining \& Mfg. Co. v. International Plastic Corp., I59 F. 2d 554 (C.C.A. 7th, I947) (distributor's place of business not defendant's "place of business" within patent infringement venue statute).

sx The artificiality of corporate personality is responsible for an analogous problem in the case of the wholly-owned subsidiary corporation resident or doing business in the state and the defendant parent corporation organized elsewhere. These facts alone were held insufficient to give courts of the subsidiary's state jurisdiction over the parent in State v. Northwest Magnesite Co., 28 Wash. 2d I, I82 P. 2d 643 (1947), the court following Cannon Mfg. Co. v. Cudahy Packing Co., 267 U.S. 333 (1925); cf. Schenstrom v. Continental Machines, Inc., 7 F.R.D. 434 (N.Y., I947) (foreign corporation and local partnership both wholly owned and directed by one family; jurisdiction over partnership not jurisdiction over corporation although partnership was exclusive selling outlet of corporation). But where the officers of both are the same persons, and they manage the defendant from within the state, the opposite result has been reached. Pickthall v. Anaconda Copper Mining Co., 73 F. Supp. 694 (N.Y., I947) ("doing business" within F.E.L.A. venue provision); In re Grand Jury Subpoenas Duces Tecum, 72 F. Supp. Ior 3 (N.Y., I947) ("found" within district under Clayton Act).

52 Cases cited notes 20, 22, 26, 28, 46, 49 supra; Grace v. Proctor \& Gamble Co., 57 A. 2d 6 ig (N.H., I948); Winkler-Koch Engineering Co. v. Universal Oil Prod. Co., 70 F. Supp. 77 (N.Y., 1946).

53 The International Shoe decision has received no mention at all in at least twenty subsequent cases, although they involved situations to which its authority extends.

54 See, for example, Central Motor Lines v. Brooks Transp. Co., 225 N.C. 733, 36 S.E. 2d 27 (1945).

${ }^{55}$ See, for example, Yedwab v. M. A. Richards Corp., I37 N.J.L. 448, 60 A. 2d $3^{\text {Io }}$ (1948); Myers Motors, Inc. v. Kaiser-Frazer Sales Corp., 80 F. Supp. 88 (Minn., I948); Schenstrom v. Continental Machines, Inc., 7 F.R.D. 434 (N.Y., 1947).

${ }^{56}$ L. Hand, J., in Bomze v. Nardis Sportswear, Inc., 165 F. $2 d$ 33, 37 (C.C.A. $2 d$, 1948). 


\section{II}

Anything said about jurisdiction over individuals or partnerships in International Shoe Co. v. Washington is necessarily dictum. However, the discussion of jurisdiction over foreign corporations in the opinion was introduced by reference to jurisdiction over individuals:

[N] ow that the capias ad respondendum has given way to personal service of summons or other form of notice, due process requires only that in order to subject a defendant to a judgment in personam, if he be not present within the territory of the forum, he have certain minimum contacts with it such that the maintenance of the suit does not offend "traditional notions of fair play and substantial justice."s7

There seems no reason that a continuous course of business conducted by the agents of a nonresident individual should not be considered the equivalent of such "minimum contacts." The nonresident businessman may profit just as much from dealing with the state's citizens as a foreign corporation. The hardship is just as great if one of those citizens meets with jurisdictional objections when he seeks, in the courts of his state, to assert a claim arising out of the business done by the nonresident within the state..$^{8}$ "Traditional notions of fair play and substantial justice" surely require that the nonresident doing business in the state be compelled to defend, in the courts of the state, causes of action arising out of the business done there. The International Shoe opinion suggests that the jurisdictional theories pertaining to corporations and those relating to individuals have at last coalesced..$^{59}$ The case of Flexner v. Farson, ${ }^{60}$ which was once thought to block the assertion of jurisdiction over nonresident individuals not present within the state, has long since been distinguished. ${ }^{6 x}$ The fact that a state does not have the power to exclude a nonresident individual is of no consequence, for the power of a state to exclude a corporation from intrastate business no longer has any bearing on jurisdiction over a foreign corporation in the absence of express consent, the doctrine of "implied consent" being dead. It may be concluded that it is entirely reasonable to expect that a statute, providing for proper service of process on nonresident individuals whose agents do business within the state and for jurisdiction over the nonresidents with respect to causes of action arising out of those activities, would today be found constitutional. ${ }^{62}$

57 International Shoe Co. v. Washington, $3^{26}$ U.S. $3^{\text {Io, }} 3^{\text {I6 (I945). }}$

${ }^{8}$ Indeed, many foreign corporations may be forced to expressly consent to the jurisdiction of the state's courts before they do business in the state, while this condition cannot be imposed on individuals. Thus, if jurisdiction depended entirely upon express consent, one dealing with nonresident individuals would more often be forced to take his claims to another state than one dealing with foreign corporations.

${ }^{59}$ See note 35 supra for another aspect of the suggested joinder.

${ }^{60} 248$ U.S. 289 (rgrg).

${ }^{6 *}$ Scott, Jurisdiction over Nonresidents Doing Business within the State, 32 Harv. L. Rev. 87 I, 890 (x9I9).

63 This position was taken in Rest., Judgments $\$ 22$ (I942), largely on the basis of the Supreme Court's holding in Henry L. Doherty \& Co. v. Goodman, 294 U.S. 623 (I935). How- 
Such was the holding of the Arkansas Supreme Court in a recent case. ${ }^{63}$ The court recognized the relevance of the International Shoe decision to the question before it, ${ }^{64}$ and held that the statute ${ }^{65}$ did not violate any constitutional right of the nonresident defendant:

It does not violate the due process clause since it requires a legal basis for jurisdiction, that is the nonresident, defendant, must have done some business, work or service within the State. It does no violence to the privileges and immunities clause because it does not discriminate between non-residents but places them upon the same basis as residents. ${ }^{66}$

Similar statutes are in force in other states, ${ }^{67}$ and foreign corporation cases are often looked to in determining what activities constitute "doing business" by the individual. ${ }^{68}$ The International Shoe case may therefore become a significant

ever, the Court in that decision had expressly limited itself to the particular facts of the situation there presented. Tbid., at 628 . The Court carefully noted the fact that the defendarit's business, that of dealing in corporate securities, was subjected to special regulation by the state. It was thus suggested that the case might be only a slight extension of the principle of Hess v. Pawloski, 274 U.S. 352 (I927), that a nonresident's acts which are of a sort dangerous to life or property may provide the basis for jurisdiction as to causes of action arising out of such acts. "Both the sale of securities and the operation of motor vehicles are fraught with danger and economic harm to the general public." Goodrich, Conflict of Laws $\& 70$, at $x 68$ (1938). The idea originating from the nonresident motorist cases was carried a little further in Sugg v. Hendrix, 142 F. 2d 740 (C.C.A. 5th, I944), where the application of a Mississippi statute (Miss. Code Ann. [I944] \& I437) was held constitutional. The statute provided for jurisdiction over nonresident individuals doing business in the state without discriminating between types of business. However, the defendant's Mississippi business was the construction of a levee, and the court, emphasizing the hazardous nature of construction work and relying on the nonresident motorist cases, was careful to limit itself to the facts at hand. The court thought the statute, as there applied, was a reasonable exercise of the police power of the state. Compare Dubin v. Philadelphia, 34 Pa. D. \& C. 6I (1938) (nonresident owner or user of local real estate).

${ }^{6} 3$ Gillioz v. Kincannon, 2I4 S.W. 2d 212 (Ark., I948). Accord: Wein v. Crockett, I95 P. 2d 222 (Utah, 1948); Ritholz v. Dodge, 210 Ark. 404, I96 S.W. 2d 479 (I946); see Interchemical Corporation v. Mirabelli, 269 App. Div. 224, 54 N.Y.S. $2 d 522$ (I945). In the Wein case, the court observed: "If the cause of action arises in this state, out of business transacted in this state, the probabilities are that the witnesses will be readily available here; the law of this state will control and determine the cause of action; and the courts here would be the forums of convenience for the trial of the action. To require a resident who is transacting business in this locality to commence his action in a foreign jurisdiction on a cause of action arising here, and transport his witnesses to other states would make protection of his right prohibitive and would, in effect, permit nonresidents to continue in business in this state immune from legal responsibility." Wein v. Crockett, supra, at 228-29.

${ }_{64}$ Gillioz v. Kincannon, 2I4 S.W. 2d 212, $2 I_{5}$ (Ark., I948). The Arkansas court relied on the language in the International Shoe decision quoted in text at note 57 supra.

65 Ark. Acts (r947) No. 347.

${ }^{66}$ Gillioz v. Kincannon, 214 S.W. 2d 212, 216 (Ark., I948).

${ }^{67}$ See, e.g., Ky. Codes Ann. (Carroll, I948), Civ. Prac. Code $\$ \$ 5 I-56 ;$ N.Y. Civ. Prac. Ann. (Cahill, r946) § 229-b; Utah L. (1947) c. xo.

68 As in Melvin Pine \& Co. v. McConnell, 298 N.Y. 27, 80 N.E. 2 d 137 (I948); Kaffenberger v. Kremer, 63 F. Supp. 924 (Pa., I945); Debrey v. Hanna, I82 N.Y. Misc. 824, 45 N.Y.S. 2d $55 \mathrm{I}_{4}(\mathrm{rg43})$. 
precedent on this question. This was forcefully recognized in a case in one of the lower New York courts, ${ }^{69}$ in which the defendant partners' motion to dismiss was at first granted. This decision was recalled and the motion denied on reargument, after the court had "been advised of the latest pronouncement of the United States Supreme Court [the International Shoe case] upon the subject of what activities of a non-resident within a state will subject such non-resident to jurisdiction." ${ }^{70}$ On appeal, the lower court's decision was affirmed on the basis of the "long-recognized test of what constitutes engaging in business. . . " "7 However, the Court of Appeals, for unstated reasons, said:

It is unnecessary, at this time, to say whether and to what extent that test may be relaxed in reliance upon the constitutional principles recently announced by the Supreme Court in International Shoe Co. v. Washington. . . . .72

The cautious reluctance of the New York court seems unnecessary. Even though the principles of the International Shoe case would not necessarily result in a relaxation of the "test" mentioned, those principles might reasonably be relied upon in actions against nonresident individuals engaging in business within the state.

It has generally been conceded that, in states in which partnerships and unincorporated associations are subject to suit as entities, nonresident organizations of this nature may be treated jurisdictionally in the same manner as undomesticated foreign corporations. That is, a nonresident partnership doing business in such a state is subject to suit there in causes of action arising out of the business done in the state.73 This jurisdiction was not thought to apply to the partners as individuals. ${ }^{74} \mathrm{~A}$ statute providing for jurisdiction over the nonresident partners individually would appear to be valid today, in view of the principles discussed above with regard to individuals. Again, the standards of the International Shoe case as to the extent of activities within the forum which is necessary for jurisdiction should be influential in partnership cases.

The implications here drawn from International Shoe Co. v. Washington take on added significance when it is realized that they are part of a dual trend in jurisdictional decisions: in defining the court with jurisdiction, a trend from the court with immediate power over the defendant to the court where both parties may most conveniently settle their dispute; and in defining due process of law, a trend from emphasis on the territorial limitations of courts to emphasis on providing notice and an opportunity to be heard. The International Shoe case may thus be expected to continue to gain in importance.

69 Melvin Pine \& Co. v. McConnell, 64 N.Y.S. 2d 814 (Sup. Ct., I946), aff'd 273 App. Div. I 28,76 N.Y.S. 2 d 279 (1948).

70 Ibid., at $8 \mathrm{I}_{4}-\mathrm{I} 5$.

$7 x$ Melvin Pine \& Co. v. McConnell, 298 N.Y. 27, 80 N.E. 2d I37 (I948).

72 Ibid. (Italics added).

73 Rest., Conflict of Laws $\S 86$ (I934); x Beale, Conflict of Laws $\$ 86.1$ (I935).

74 Western Mut. Fire Ins. Co. v. Lamson Bros. \& Co., 42 F. Supp. 1007 (Iowa, I94I); I Beale, Conflict of Laws $\$ 86.1$ (r935). 